\title{
Comparison of the development of cluster and non-cluster models of corn farming
}

\author{
Triwara Buddhi Satyarini", Dindha Timor Pangarso \\ Department of Agribusiness, Faculty of Agriculture, Universitas Muhammadiyah Yogyakarta, \\ Indonesia
}

\begin{abstract}
Corn is the potential commodity in Grobogan Regency. Considering that potential, Bank Indonesia, in cooperation with the Government of Grobogan, creates the development program of corn cluster. The selected area was Gapoktan Sido Murni in Tambakselo Village. However, there was an area with the same potential that doesn't have a cluster development program, which is Gapoktan Sido Manunggal in Dokoro Village. Therefore this research aims compare the income, profit, and feasibility of corn farming. The number of respondents was 20 farmers in each village and was determined by a non-random sampling. The data obtained were analyzed descriptively. The results showed that farmers of Gapoktan Sido Murni earned an average income of IDR $11,724,722$ and a profit of IDR 7,917,851. Meanwhile, farmers in Gapoktan Sido Manunggal earned an average income of IDR 9,740,915 and a profit of IDR 5,991,161. The R/C in Gapoktan Sido Murni was 1.9 while Gapoktan Sido Manunggal had 1.6, land productivity in Gapoktan Sido Murni was IDR 9,928,684/Ha/season and Gapoktan Sido Manunggal was IDR 7,991,161/Ha/season, and capital productivity in Gapoktan Sido Murni $148 \%$ and Dokoro 104\%. Based on the feasibility analyses, Gapoktan Sido Murni had a higher feasibility value than Gapoktan Sido Manunggal; thus, the corn cluster program is worth developing.
\end{abstract}

\section{Introduction}

Corn is a commodity used as a staple food as well as an industrial raw material. In addition, corn also can be a buffer for national food security. Corn has nutritional value (carbohydrates, proteins, fats, minerals) comparable to rice, and corn farming requires high labor.

According to BPS [1], the largest land and production in Central Java is Grobogan Regency. The land area of $90,348 \mathrm{Ha}$ in $2011 ; 100,332 \mathrm{Ha}$ in 2012; 98,909 Ha in 2013; $105,447 \mathrm{Ha}$ in 2014, and 112,700 ha in 2015. The land area for maize in Grobogan Regency has increased from year to year, with a decrease in 2013 by 1,423 ha land area. Grobogan Regency's corn production is stated as a national barometer. Suitable land and climate were the main reason why corn is a commodity in Grobogan Regency, which has

\footnotetext{
* Corresponding author: triwarabs@gmail.com
} 
been able to meet the needs of its people and even surplus. It is the primary reason to create the development corn farming cluster.

In the development center area of the cluster model, facilitators (District and Bank Indonesia Governments) facilitate the development of cluster areas in the form of counseling, special training, providing more adequate facilities and infrastructure, and introducing new technologies. It is expected to increase the productivity in the cluster development center [2]. The corn cluster development center in Grobogan District was built in 2015 in Tambakselo Village, Wirosari District. Meanwhile, Dokoro Village in Wirosari Subdistrict is an area that has not received a cluster development program yet. The soil conditions, climate, temperature, and weather are the same as Tambakselo Village. In addition, Dokoro Village also produces corn throughout the year, such as Tambakselo Village. According to the BPS [1], in Wirosari Subdistrict, Dokoro Village has the largest maize area, an area of 1,232 Ha. On the other hand, the area of maize is in Tambakselo Village, $924 \mathrm{Ha}$.

This condition aligns with Prasetyo \& Eko's [3] study concerning the cluster typology of the corn processing industry in Merakurak sub-district, Tuban. Based on the characteristics of local economic development, corn cluster areas have superiority and potential raw materials if they are developed and innovated to lead to product development diversification. Unlike this, the citrus production central that is North Mollo Subdistrict, the SWOT (Strength, Weakness, Opportunity, Threat) analysis was used as the development strategy. The feasibility analysis criteria such as NPV is more than 1, IRR is greater than Minimum Attractive Rate of Return (MARR 16\%), B/C Ratio is more than 1, BEPIDR IDR 66,753 and amounted to 11,13 units BEPunit. Thus based on those criteria, the Keprok SoE Citrus farming is feasible to be sustained [4].

A cluster development center in Tambakselo Village should influence farmers' income and profits compared to those without a cluster development program. This is because training and extension of corn farming are provided at the cluster development center so that the results can be optimized and additional support is provided. For instance, cattle farms can directly or indirectly provide additional revenue for farmers. However, not all activities and results of the training are carried out. Therefore, this study was conducted to compare the income and profits of farming in the cluster and non-cluster areas. The input of corn farming at the center of the cluster development is not much different from corn farming which does not get a cluster development program. However, there is a difference in output, so it is necessary to know and compare whether the cluster area has a higher feasibility value than the non-cluster area.

This is in line with Jan Zenka et al, [5]. They asked if productivity gains from the average large plots are higher than potential losses resulting from land tenure (tenants are generally less productive than farmland owners). According to the case study of Czechia, a country with extremely fragmented farmland ownership, but the largest average size of plots in the EU and a strong role of farmland rental market and that land-use fragmentation negatively affects microregional agricultural labor productivity. The average larger size of plots is positively related to microregional agricultural labor productivity despite potentially negative effects of land tenure. No significant effects of urbanization economies and farm size structure, at the same time.

\subsection{Literature Review}

Corn farming also requires high labor because of the availability of land that is still large enough for its development. Corn commodities are relatively easy in their cultivation [6]. The other opinion, with the high potential of corn, Bank Indonesia (BI) Central Java 
Province, in collaboration with the Grobogan Regency Government, created a development program of corn farming cluster [7].

In Chuka and Thika in Kenya, a farming system basically on maize was compared for six years. Yields of the organic system on high input are equal to conventional, except in the first year at Thika. Intercropping of maize-bean organic systems yielded as conventional one in low input. But in costs, organic production in high and low input was higher than conventional ones. From the $5^{\text {th }}$ year, organic was more profitable than conventional in the high input systems. Conventional systems exported more nutrients than organic systems [8].

Rural development related to agriculture can roughly be divided into two trajectories: 1) agri-industrial development or modernization, and 2) multifunctional or even postproductivist rural development. The role of these trajectories varies in different rural settings, with different emphases on agricultural production and its conduct. The trajectories evolve from existing farming practices and their connections at the farm level, which enable or disable different kinds of development. The interconnectedness of farms following different development trajectories demonstrates the persistence and evolution of traditional sharing and bartering practices. This calls for further exploration of differences in rural development in different regional farming contexts [9].

Sustainable economic development, food security, and environmental management are some of the highest priorities of the modern world because they are related to present and future generations [10]. Following the guidelines for Replication of Bank Indonesia Activities in Supporting Superior Commodity Cluster-Based Food Security). The development is carried out with regional models that experience a certain surplus of food. [11].

Compared with the study results of the benefits of hybrid corn farming in Lombok regency (IDR 4,173,000/Ha/planting season), the benefits of corn farming in Tambakselo (cluster system) are higher than is IDR 7,917,851 / ha/planting season [11].

In the U.S. Heartland (Corn Belt) region, by quinquennial Agricultural Census data from 1982 to 2012, the study also compares TFP growth rates across farm sizes to determine whether observed productivity differences are likely to persist. The finding of a strong positive relationship between farm size and TFP suggests that consolidation of production has contributed to recent aggregate productivity growth in the crop sector. The study estimates how sectoral productivity growth can be attributed to structural change versus other factors, including technological change. The study also explores some tradeoffs associated with policies that raise the productivity of small versus large farms [12].

\section{Research Methods}

This research used the descriptive analysis method. The location of the study was conducted purposively in Tambakselo Village and Dokoro Village, Wirosari District, Grobogan Regency. The sample was determined by non-random sampling with 20 respondents per village or 40 total respondents. The primary data collection technique was done by interview, observation, and questionnaire. The secondary data were obtained from the Central Statistics Agency (BPS), Grobogan District Agricultural Service, UPTD Office (Regional Technical Implementation Unit) of Wirosari District, and Gapoktan Sido Murni (Tambakselo Village) and Gapoktan Sido Manunggal (Dokoro Village). The data obtained were analyzed descriptively. Corn farming is analyzed by cost analysis, income, profit, R / $\mathrm{C}$, land productivity, labor productivity, and capital productivity, according to Soekartawi, 1995. 
Total Cost is accumulated of explicit cost and implicit cost

$$
T C=T E C+T I C
$$

TC $\quad=$ Total Cost (Biaya Total)

TEC $=$ Total Explicit Cost

TIC $=$ Total Implicit Cost

Net revenue of farming can calculate by this formula:

$$
\begin{aligned}
N R & =T R-T E C \\
T R & =Y . P y
\end{aligned}
$$

$\begin{array}{ll}\text { NR } & =\text { Net Revenue } \\ \text { TR } & =\text { Total Revenue } \\ \text { TEC } & =\text { Total Explicit Cost } \\ \text { Y } & =\text { Product of farming } \\ \text { Py } & =\text { Price of product }\end{array}$

Profit is total revenue reducted by total cost explicit and implicit:

$$
\begin{array}{ll}
\Pi & \quad \Pi=T R-(T E C+T I C) \\
\text { TR } & =\text { Profit } \\
\text { TEC } & =\text { Total Explicit Cost } \\
\text { TIC } & =\text { Total Implicit Cost }
\end{array}
$$

For review feasibility of farming using the calculation result of $\mathrm{R} / \mathrm{C}$, Land productivity, labour productivity, capital productivity

$\mathrm{R} / \mathrm{C}>1$

$\mathrm{R} / \mathrm{C}$ is a comparison between total revenue and total cost of farming (Soekartawi, 1995).

$$
\begin{array}{llr} 
& R / C=T R / T C \\
\mathrm{R} / \mathrm{C} & =\text { Revenue Cost Ratio } & \\
\mathrm{TR} & =\text { Total Revenue } \\
\mathrm{TC} & =\text { Total Cost }
\end{array}
$$

Land productivity results can be obtained from farming per land area.

Land productivity $=(N R-$ cost of the family labour force - the cost of interest of selfcapital)/(land area)

$\mathrm{NR}=$ Net Revenue

Labor productivity is a comparison of total revenue and total man-days per farming in IDR /man-days.

Labor productivity $=(N R-$ the cost of rent of self-land area - the cost of interest of selfcapital)/(total man-days)

$\mathrm{NR}=$ Net Revenue

Capital productivity is a comparison of profit and total cost per farming. 
Capital productivity $=(N R-$ the cost of the family labour force - the cost of rent of self-land area)/TECX100\%

$$
\begin{array}{ll}
\mathrm{NR} & =\text { Net Revenue } \\
\mathrm{TEC} & =\text { Total Explicit Cost }
\end{array}
$$

\section{Result \& Discussion}

Bank Indonesia is one of the organizations that act as a controller of inflation. One of the ways to do so is by controlling regions that have a surplus of commodities. Bank Indonesia invites regional governments with surplus commodities to serve as a cluster development center. In 2015, Bank Indonesia looked for areas used as cluster development centers in Grobogan Regency. The area chosen as the cluster development center was Kedungjati District and Wirosari District, which later became the center of corn cluster development integrated with cattle farms.

The role of Bank Indonesia in the cluster development program is to provide facilities and infrastructure that support the cluster development program. Bank Indonesia provides equipment and training related to corn farming and cattle farming. The equipment provided by Bank Indonesia is a tool for making organic fertilizers, TOSA motors, corn dryers, moisture gauges, cultivators, corn threshers, corn ovens, communal cattle cage corn cobs, and cow scales. Bank Indonesia also provides training related to agriculture, livestock, and institutions. The training provided is in making compost fertilizer from cow manure, making animal feed from corn harvesting waste, making biological insecticides, strengthening institutions, cooperatives, and providing knowledge about exports.

The Grobogan District Animal Husbandry Service also assists with PO types (Ongole Breeds) to be filled in communal cages. The concept promoted by Bank Indonesia for the cluster development center at Gapoktan Sido Murni is zero residues. Zero residues are agriculture with no waste, so everything on corn and cattle farming must be utilized and processed. Zero residues applied at Gapoktan Sido Murni, namely harvest waste from corn (kelobot and hump), are fermented into animal feed. According to Febrina \& Mairika's research [13] on the utilization of agricultural waste as ruminant feed on people's farms in Rengat Barat Subdistrict, Indragiri Hulu Regency, it is evident that the development of beef cattle in an area is the appropriate time to take advantage of an agricultural waste considering the availability of grass and other forages.

According to Febrina \& Mairika's research [13] on the utilization of agricultural waste as ruminant feed on people's farms in Rengat Barat Subdistrict, Indragiri Hulu Regency, it is evident that the development of beef cattle in an area is the appropriate time to take advantage of an agricultural waste considering the availability of grass and other forages. The animal feed is given to cows in communal cattle pens. The cow dung in communal cattle pens is then processed into biogas which is then used as an electricity source for agricultural equipment and stoves in the residential housing. According to Yulianto et al. [14], in his research of the potential utilization of biogas as an electric energy generator in Kalsimpanang Hamlet, Hargobinangun, Pakem, Sleman, Yogyakarta, biogas has enormous potential to be developers as an alternative source by converting biogas into electrical energy.

\subsection{Farming Analysis}

Total costs are the sum of explicit costs and implicit costs. Result of corn farming in Tambakselo (cluster) and Dokoro (non-cluster) 
Table 1. Total Costs for Farming in Tambakselo Village and Dokoro Village per $1 \mathrm{Ha}$

\begin{tabular}{|l|r|r|}
\hline Cost type & Tambakselo Village (IDR) & Dokoro Village (IDR) \\
\hline Explicit Fees & $3,300,090$ & $4,189,640$ \\
\hline Production Facilities & 99,068 & 90,497 \\
\hline Tool Depreciation & $1,640,714$ & $1,382,083$ \\
\hline TKLK & 444,156 & 281,465 \\
\hline Etc & $5,484,028$ & $5,943,685$ \\
\hline Total \\
\hline Implicit costs & $1,631,517$ & $1,571,443$ \\
\hline TKDK & $2,000,000$ & $2,000,000$ \\
\hline Land lease & 164,521 & 178,311 \\
\hline Capital Interest & 10,833 & 0 \\
\hline Tool Depreciation & $\mathbf{3 , 8 0 6 , 8 7 1}$ & $\mathbf{3 , 7 4 9 , 7 5 4}$ \\
\hline Total & $\mathbf{9 , 2 9 0 , 8 9 9}$ & $\mathbf{9 , 6 9 3 , 4 3 9}$ \\
\hline Total cost &
\end{tabular}

A striking difference from the description of costs on maize farming in Tambakselo Village and Dokoro Village is a means of production. The maize farmers in Dokoro Village use more production facilities because they hope that the obtained results can be as maximum as possible. The second difference is that there is no depreciation of equipment at implicit costs in Dokoro Village because corn farmers in Dokoro Village buy all the equipment themselves. The means that no equipment is obtained from government assistance.

Revenue is the number of products produced from the production process multiplied by the prevailing price in the market.

Table 2. The Revenue of Corn Farming in Tambakselo Village and Dokoro Village per $1 \mathrm{Ha}$

\begin{tabular}{|l|r|r|r|r|r|r|}
\hline \multirow{2}{*}{ Description } & \multicolumn{3}{|c|}{ Tambakselo Village (cluster) } & \multicolumn{3}{c|}{ Dokoro Village (non-cluster) } \\
\cline { 2 - 7 } & Total & $\begin{array}{c}\text { Price } \\
\text { (IDR) }\end{array}$ & $\begin{array}{c}\text { Receipt } \\
\text { (IDR) }\end{array}$ & \multicolumn{1}{c|}{ Total } & $\begin{array}{c}\text { Price } \\
\text { (IDR) }\end{array}$ & $\begin{array}{c}\text { Receipt } \\
\text { (IDR) }\end{array}$ \\
\hline Corn Flour (kg) & 4,190 & 4,000 & $16,760,000$ & 4,357 & 3,600 & $15,684,600$ \\
\hline Klobot Bump (sack) & 90 & 5,000 & 448,750 & 0 & 0 & 0 \\
\hline Total & & & $17,208,750$ & & & $15,684,600$ \\
\hline
\end{tabular}

There are differences in products sold between corn farmers in Tambakselo Village and Dokoro Village. Corn farmers in Tambakselo Village do sell shelled not only corn but also sell skin and corncob, which are corn harvest waste. On the other hand, corn farmers in Dokoro Village only sell corn. This is because skin and corncobs in Tambakselo Village are used and processed as cattle feed, so they are sold. The farmers obtained the ways to process corn crop waste from the training provided by Bank Indonesia in the cluster development program. In addition to giving more income for farmers, corn harvest waste is not wasted because many people have switched from traditional stoves where corn harvesting waste is only used as conventional stove fuel. The selling price of shelled corn in Tambakselo Village and Dokoro Village is also different. The difference is due to the location of Dokoro Village compared to Tambakselo Village, so that the middlemen who bought corn in Dokoro Village reduced the selling price for transportation. According to Saputra et al. [15] in his research on Analysis of Pipil Corn Farming National Special Efforts Program (UPSUS) in Tebing Tinggi Okura Village, Pekanbaru Rumbai Pesisir Subdistrict, the farming of pipile corn farmer groups in Tebing Tinggi Okura Village produced approximately $1,414 \mathrm{~kg}$ with a selling price of IDR $3,500 / \mathrm{kg}$, so that the amount of IDR 4,950,000 /ha/planting season is obtained. This shows that revenues from both the cluster and non-cluster areas are higher because of higher production and selling prices. 
Revenue obtained from total corn farmer receipts is reduced by the total explicit costs incurred.

Table 3. Revenue of Corn Farming in Tambakselo Village \& Dokoro Village per Ha

\begin{tabular}{|c|c|c|}
\hline \multirow{2}{*}{ Description } & Tambakselo Village (cluster) & Dokoro Village (non-cluster) \\
\cline { 2 - 3 } & Amount (IDR ) & Amount (IDR ) \\
\hline Revenue & $17,208,750$ & $15,684,600$ \\
\hline Explicit Fees & $5,484,028$ & $5,943,685$ \\
\hline Net Revenue & $11,724,722$ & $9,740,915$ \\
\hline
\end{tabular}

The income of farmers in the cluster development center is higher than in the noncluster area. If corn farmers in Dokoro Village want to increase income, farmers have to maximize their income. In addition, farmers can minimize explicit costs so that income increases. According to Saputra et al. [15] in his research on the Analysis of Pipil Corn Farming National Special Efforts Program (UPSUS) in Tebing Tinggi Okura Village, Pekanbaru Rumbai Pesisir Subdistrict, the income obtained was IDR 1,094,724 / ha/planting season. Pipil corn income in the Special Efforts National Program in Tebing Tinggi Okura Subdistrict, Rumbai Pesisir Subdistrict, Pekanbaru City is different from the income in the Corn Cluster Development Program. Such low production is due to uncertain climate and the effects of land and forest fires. In addition, farmers are still very dependent on government assistance (fertilizer, seeds, and agricultural equipment) so that farmers become less independent. The advantage is the amount of income reduced by implicit costs.

Table 4. Profit of Corn Farming in Tambakselo Village and Dokoro Village per $1 \mathrm{Ha}$

\begin{tabular}{|c|c|c|}
\hline \multirow{2}{*}{ Description } & Tambakselo Village (cluster) & Dokoro Village (non-cluster) \\
\cline { 2 - 3 } & Amount (IDR ) & Amount (IDR ) \\
\hline Net Revenue & $11,724,722$ & $9,740,915$ \\
\hline Implicit costs & $3,806,871$ & $3,749,754$ \\
\hline Profit & $7,917,851$ & $5,991,161$ \\
\hline
\end{tabular}

The average profit obtained by corn farmers in Tambakselo Village is higher than that of Dokoro Village. This is because the income received by farmers is higher while the costs are generally lower. If corn farmers in Dokoro Village want to increase profits, they can reduce implicit costs. According to Purwanto et al. [14], in the study of Analysis of Hybrid maize farming production and income in Modo Village, Bukal District, Buol District, the average profit of Hybrid Maize respondents in Modo Village was IDR 5,984,661 / 1,18 ha or IDR $5,771,746 / 1.00$ ha for one planting season. This shows that the existence of a cluster program significantly improves the farmers' income which is higher compared to that of a cluster program.

$\mathrm{R} / \mathrm{C}$ analysis is a comparison of income obtained by farmers with total costs. $\mathrm{R} / \mathrm{C}$ is said to be feasible if the value is more than $(>) 1$.

Table 5. R / C Analysis of Corn Farming in Tambakselo Village and Dokoro Village

\begin{tabular}{|l|l|}
\hline Tambakselo Village (cluster) & Dokoro Village (non cluster) \\
\hline $\mathrm{R} / \mathrm{C}=\frac{\mathrm{TR}}{\mathrm{TC}}$ & $\mathrm{R} / \mathrm{C}=\frac{\mathrm{TR}}{\mathrm{TC}}$ \\
\hline $\mathrm{R} / \mathrm{C}=\frac{17,208,750}{9,290,899}$ & $\mathrm{R} / \mathrm{C}=\frac{15,684,600}{9,693,439}$ \\
\hline $\mathrm{R} / \mathrm{C}=1.9$ & $\mathrm{R} / \mathrm{C}=1.6$ \\
\hline
\end{tabular}


The value of $\mathrm{R} / \mathrm{C}$ in Tambakselo Village is 1.9. This means that every IDR 1 - costs paid, then generate revenues are of IDR 1.9. Based on the calculation of $\mathrm{R} / \mathrm{C}$, corn farming is feasible because of $\mathrm{R} / \mathrm{C}>1$. Meanwhile, the $\mathrm{R} / \mathrm{C}$ value in Dokoro Village is 1.6. The value of R / C 1.6 means that every IDR 1 - costs paid generates revenues of IDR 1,6. Based on the calculation of $\mathrm{R} / \mathrm{C}$, corn farming is feasible because of $\mathrm{R} / \mathrm{C}>1$. According to Khotimah [16] in her research on the feasibility of corn farming in Ciamis Regency, the results showed that maize farming in Ciamis District, whose implementation was combined with livestock cultivation, had an $\mathrm{R} / \mathrm{C}$ value of 2.22 . The $\mathrm{R} / \mathrm{C}$ value was greater than the cluster development area because the productivity of maize in the Ciamis Regency reached 6.05 tons/ha. In comparison, productivity in the cluster development area was 4.5 tons / Ha. This is due to the use of different seed varieties. In Ciamis Regency, most farmers use hybrid varieties, and they also utilize Bisi 18 in the cluster development.

Land productivity analysis is a comparison between the reduction of income, costs of the family labor force, and the cost of own capital with the area cultivated by farmers. Land productivity is to be feasible if it is greater than the price of renting local land.

Land rental prices in Tambakselo Village and Dokoro Village are IDR 2,000,000 per Ha per planting season. The value of land productivity in one planting season in Tambakselo Village is IDR 9,928,684 / Ha/planting season. Land productivity in Dokoro Village is IDR 7,991,161 / Ha/planting season. This means that agricultural land owned by corn farmers in Tambakselo Village and Dokoro Village is better used alone than rented because land rental prices are lower than land productivity. According to Islam et al. [17], who researched the Feasibility of summer corn (Zea mays L.) production in China's affected northern areas using superabsorbent polymeric water-saving, production of corn is even higher in summer. Climate and the condition of the land also affect the yield of corn, so that the right technology is needed to increase production. Although land productivity in the cluster and non-cluster areas is feasible, it can be further improved by processing land with the right technology.

Table 6. Land Productivity in Corn Farming in Tambakselo Village and Dokoro Village

\begin{tabular}{|l|c|}
\hline \multicolumn{1}{|c|}{ Tambakselo Village (cluster) } & Dokoro Village (non-cluster) \\
\hline $\begin{array}{c}\text { Land Prod }=\left(\begin{array}{c|}\text { NR-Fee TKDK-Own Interest } \\
\text { Interest Cost }) /(\text { Land Area })\end{array}\right. \\
\text { Land Prod }=(11,724,722-1,631,517-164,521) / 1\end{array}$ & $\begin{array}{c}\text { Land Prod }=(\text { NR-Fee TKDK-Own Interest } \\
\text { Interest Cost }) /(\text { Land Area })\end{array}$ \\
\hline Land Prod $=(9,928,684) / 1$ & Land Prod $=(9,740,915-1,571,443-178,311) / 1$ \\
\hline Land Prod $=9,928,684$ & Land Prod $=7,991,161 / 1$ \\
\hline
\end{tabular}

The analysis of labor productivity is a comparison between the reduction of income, the cost of renting the land itself, and the cost of own interest with the number of workers in the family. Labor productivity is feasible if the value is greater than the wages of farm laborers in Tambakselo Village and Dokoro Village. The average salary of people living in Tambakselo village and Dokoro village is IDR 50,000-.

The value of labor productivity in Tambakselo Village is IDR 292,361/ HKO, and Dokoro Village IDR 240,847 / HKO. The value of land productivity is greater than the daily wage. They were earned by people living in Tambakselo Village and Dokoro Village, IDR 50,000 / HKO. This implies that farmers better work on their corn farm rather than workers on other's fields. According to Mardani et al. [18], in the study of Analysis of corn food crop farming in the July District of Bireuen District, low productivity resulted in a low income of farmers. In cluster and non-cluster areas, labor productivity is more than the prevailing wage in the community. This indicates that productivity in both regions is not low. 
Table 7. Labor Productivity in Corn Farming in Tambakselo Village and Dokoro Village

\begin{tabular}{|c|c|}
\hline \multicolumn{1}{|c|}{ Tambakselo Village (cluster) } & Dokoro Village (non-cluster) \\
\hline $\begin{array}{c}\text { Labor Prod. }=(\text { NR-Self-Rent Land-Interest Cost) } \\
/(\text { Number of TKDK }(\text { HKO })\end{array}$ & $\begin{array}{c}\text { Labor Prod. }=(\text { NR-Self-Rent Land-Interest Cost }) \\
/(\text { Number of TKDK }(H K O)\end{array}$ \\
\hline Labor Prod. $=(11,724,722-2,000,000-164,521)$ & Labor Prod. $=(9,740,915-2,000,000-178,311)$ \\
$/(32.7)$ & $/(31.4)$ \\
\hline Labor Prod. $=(9,560,201) /(32.7)$ & Labor Prod. $=(7,562,604) /(31.4)$ \\
\hline Labor Prod. $=292,361$ & Labor Prod. $=240,847$ \\
\hline
\end{tabular}

Capital productivity is the ratio between income reduction, labor costs in the family, and own land rent with explicit costs. Then the result is multiplied by $100 \%$. Capital productivity is feasible if the value is greater than the bank loan interest rate of $3 \%$ for one planting season.

Table 8. Capital productivity in corn farming in Tambakselo Village and Dokoro Village

\begin{tabular}{|c|c|}
\hline Tambakselo Village $($ cluster $)$ & Dokoro Village (non-cluster) \\
\hline Capital Prod $=($ NR-Fee TKDK-Land Lease $)$ & Capital Prod $=($ NR-Fee TKDK-Land \\
Lease $) /$ TEC $\times 100 \%$ \\
\hline Capital Prod $=(11,724,722-1,631,517-$ \\
$2,000,000) /((5,484,028) \times$ & Capital Prod $=(9,740,915-1,571,443-$ \\
$100 \%)$ & $2,000,000) /((5,943,685) \mathrm{x}$ \\
$100 \%))$
\end{tabular}

The value of capital productivity in corn farming in Tambakselo Village is $148 \%$. This means that corn farming in Tambakselo Village is feasible because it is bigger than the bank loan of $103 \%$ (3\% loan interest rate). Meanwhile, the value of capital productivity in corn farming in Dokoro Village is $104 \%$ which means that corn farming in Dokoro Village is feasible because the value is greater than the bank loan of $103 \%$. If corn farmers in Tambakselo Village and Dokoro Village apply for bank loans, the bank will provide the loan because the bank considers farmers to be able to repay loans. After all, the capital productivity in the two villages is greater than the loan interest rate.

\section{Conclusion and Suggestion}

\subsection{Conclusion}

In one planting season, corn farmers in the regional cluster development program receive an average of IDR 17,208,750, an income of IDR 11,724,722, and profits of IDR $7,717,851$. This value is higher than the non-cluster area. In non-clustered areas, corn farmers received an average income of IDR 15,684,600, IDR 9,740,915, and a profit of IDR 5,991,161.

In the analysis of farming feasibility, the Revenue Cost Ratio $(\mathrm{R} / \mathrm{C})$ of corn farming in the development program area cluster is 1.9 , and the non-cluster is 1.6. In the cluster program development area, land productivity in corn farming is IDR 9,928,684 / $\mathrm{Ha}$ /planting season. The non-clustered area is IDR 7,991,161/Ha/planting season. Regarding labor productivity, corn farming produces in the cluster development program area is IDR 292,361/HKO, and the non-cluster area is IDR 240,847/HKO. Capital productivity shows that corn farming in the cluster development program area is $148 \%$, and the non-cluster area is $104 \%$. According to the feasibility analysis, corn farming in the 
cluster and non-cluster development program areas are equally feasible. However, the value is higher in the cluster development program area so that the cluster program is feasible to be developed.

\subsection{Suggestion}

The productivity of corn can be increased again by choosing the right corn seed varieties following the climate and conditions of the land. The cluster program can be used as a recommendation for Dokoro Village because it provides income, income, profits and has a higher feasibility value than non-clustered areas.

\section{References}

1. Badan Pusat Statistik Provinsi Jawa Tengah, Provinsi Jawa Tengah dalam Angka (2016).

2. A. Halim, Identifikasi Indikator Sukses Klaster (Departemen Pengembangan UMKM Jakarta, Bank Indonesia, 2014).

3. R. H. Prasetyo and E. B. Santoso, J. Tek. Pomits 3, 166 (2014).

4. C. N. Namah and D. V. Sinlae, Procedia Econ. Financ. 4, 86 (2012).

5. J. Ženka, O. Slach, L. Krtička, and P. Žufan, Appl. Geogr. 71, 83 (2016).

6. Andayani. N.N. and Bunyamin. Z., Analisis Usahatani Jagung Hibrida Pada Agroekosistem Lahan Tadah Hujan, (Balai Penelitian Tanaman Serealia: Sulawesi Selatan, 2013).

7. P. D. Putranto, BI Gandeng Pemerintah Kabupaten Grobogan Kembangkan Klaster Pertanian Jagung dan Sapi, Tribun Jateng (2015).

8. N. Adamtey, M. W. Musyoka, C. Zundel, J. G. Cobo, E. Karanja, K. K. M. Fiaboe, A. Muriuki, M. Mucheru-Muna, B. Vanlauwe, E. Berset, M. M. Messmer, A. Gattinger, G. S. Bhullar, G. Cadisch, A. Fliessbach, P. Mäder, U. Niggli, and D. Foster, Agric. Ecosyst. Environ. 235, 61 (2016).

9. S. Huttunen, J. Rural Stud. 71, 36 (2019).

10. M. K. Rafiq, R. T. Bachmann, M. T. Rafiq, Z. Shang, S. Joseph, and R. L. Long, PLoS One 11, (2016).

11. M. Fauzi, U. R., B. H., R. M., and Anna M., Kegiatan Bank Indonesia Dalam Mendukung Ketahanan Pangan Berbasis Klaster Komoditi Unggulan (Panduan Replikasi) (Bank Indonesia, Jakarta, 2014).

12. N. Key, Food Policy 84, 186 (2019).

13. D. Febrina and M. Liana, J. Peternak. 5, 28 (2008).

14. A. Z. A. Purwanto, H. Hadayani, and A. Muis, J. Agrol. 22, 205 (2015).

15. Y. S. Saputra, S. Khaswarina, and E. Tety, J. Agribisnis 19, 33 (2017).

16. A. H. Khotimah, Mimb. Agribisnis 1, 139 (2016).

17. M. R. Islam, Z. Zeng, J. Mao, A. E. E., X. Xue, and Y. Hu, Plant Soil Env. 6, 279 (2011).

18. Mardani, T. M. Nur, and H. Satriawan, J. S. Pertan. 1, 203 (2017). 